\title{
Human papillomavirus in skin tags: a case series
}

\author{
Caterina Dianzani ${ }^{1}$, Francesca Paolini ${ }^{2}$, Claudio Conforti ${ }^{1,3}$, Maria Silvestre $^{1}$, \\ Francesca Flagiello ${ }^{1}$, Aldo Venuti ${ }^{2}$
}

\begin{abstract}
1 Department of Plastic, Reconstructive and Cosmetic Surgery, Campus Bio-Medico University Hospital, Rome, Italy 2 HPV Unit, UOSD Tumor Immunology and Immunotherapy, Regina Elena National Cancer Institute, Rome, Italy 3 Dermatology Clinic, Hospital Maggiore, Piazza dell'Ospitale 1, Trieste, Italy
\end{abstract}

Key words: human papillomavirus, skin tags, fibromas, virology, HPV, skin cancer

Citation: Dianzani C, Paolini F, Conforti C, Silvestre M, Flagiello F, Venuti A. Human papillomavirus in skin tags: a case series. Dermatol Pract Concept. 2018;8(4):295-296. DOI: https://doi.org/10.5826/dpc.0804a08

Received: March 8, 2018; Accepted: April 6, 2018; Published: October 31, 2018

Copyright: $@ 2018$ Dianzani et al. This is an open-access article distributed under the terms of the Creative Commons Attribution License, which permits unrestricted use, distribution, and reproduction in any medium, provided the original author and source are credited.

Funding: None.

Competing interests: The authors have no conflicts of interest to disclose.

All authors have contributed significantly to this publication.

Corresponding author: Claudio Conforti, MD, Dermatology Clinic, Hospital Maggiore, Piazza dell'Ospitale 1, Trieste, Italy. Email: dermatologiaconforti@gmail.com

\section{Introduction}

Skin tags are benign tumors and are very common in the general population. Skin friction can cause skin rupture and can represent an access for pathogens such as HPV. This mechanism could explain a more frequent localization of skin tags in anatomical sites such as the neck or armpits. Mechanical friction and possible presence of HPV DNA were suggested as significant cofactors in the pathogenesis of soft fibromas [1].

Dianzani et al [1] highlighted the presence of HPV type 6 and 11 DNA in $88 \%$ of the 49 soft fibromas. Other studies reported a positive HPV DNA in $71.4 \%$ of biopsies from soft fibromas, whereas HPV detection rate was 13.3\% in normal skin samples. Thereafter, Al-Shaiji and Al-Buainian [3] reported that 30 individuals with soft fibromas showed positivity for HPV 6 and 11 DNA in $77 \%$ of cases. Other studies reported that $48.6 \%$ of 37 skin fibrous specimens were positive for HPV 6 and 11 DNA but they did not report any relationship between HPV and soft fibromas of patients.
These conflicting reports might reflect differences in material source, sample size, geographical distribution, and methods sensitivity. Thus, the possible association between fibromas and HPV was revised in the present work in the light of new experimental procedures [2].

\section{Case Presentation}

Twenty patients were enrolled at the dermatological clinic of the "Campus Biomedico" in Rome. The study was approved by Institutional Review Board and all patients gave informed consent to participate in this study. Anamnestic and clinicalhistological data, as well as information about risk factors such as a smoking habit and body mass index (BMI), were collected in a specially designed database and are illustrated in Table 1. The results revealed detection of cutaneous HPV and mucosal HPV in all 20 of the tested subjects.

Excisional biopsies were performed in all patients with skin tags, completely removing the lesion. Samples were stored at $+4^{\circ} \mathrm{C}$ in ThinPrep(r) and utilized for DNA and RNA extraction by commercial kits [2]. 
TABLE 1. Clinical and anamnestic data of patients

\begin{tabular}{|c|c|c|c|c|c|}
\hline Patient & Sex & Age (Years) & Anatomical Site & Mucosal HPV & Cutaneous HPV \\
\hline 1 & $\mathrm{M}$ & 77 & Back & & \\
\hline 2 & $\mathrm{~F}$ & 72 & Back & & \\
\hline 3 & $\mathrm{~F}$ & 66 & Right hip & & \\
\hline 4 & $\mathrm{~F}$ & 77 & Left ear & 18 & \\
\hline 5 & $\mathrm{~F}$ & 89 & Neck & & \\
\hline 6 & $\mathrm{~F}$ & 43 & Armpit & 18 & \\
\hline 7 & $\mathrm{~F}$ & 60 & Back & 6 & \\
\hline 8 & $M$ & 64 & Back & 18 & \\
\hline 9 & $\mathrm{~F}$ & 65 & Neck & & \\
\hline 10 & $\mathrm{M}$ & 40 & Neck & 6 & \\
\hline 11 & $\mathrm{M}$ & 71 & Armpit & & 93 \\
\hline 12 & $\mathrm{M}$ & 57 & Armpit & & 5 \\
\hline 13 & $\mathrm{~F}$ & 59 & Armpit & & \\
\hline 14 & $\mathrm{~F}$ & 41 & Armpit & & \\
\hline 15 & $\mathrm{~F}$ & 55 & Armpit & 16 & \\
\hline 16 & $\mathrm{~F}$ & 45 & Neck & & \\
\hline 17 & $\mathrm{M}$ & 20 & Back & & \\
\hline 18 & $\mathrm{~F}$ & 58 & Back & 16 & \\
\hline 19 & $\mathrm{~F}$ & 45 & Armpit & & \\
\hline 20 & M & 24 & Neck & & 174 \\
\hline
\end{tabular}

The presence of HPV DNA was detected by the polymerase chain reaction (PCR) and rolling circle amplification (RCA). Nested PCR with CP65/CP70 outer-CP66/CP69 inner, and MY09/MY11 outer-GP5+/GP6+inner primers was performed for the detection of cutaneous HPV and mucosal HPV, respectively. Amplified products were subjected to direct sequencing in an automated apparatus. Same primers were utilized for reverse-transcriptase and real-time PCR on extracted RNA. These techniques are standardized procedures that were already utilized in a previous work [2].

HPV DNA analyses showed presence of HPV in 50\% of patients. The HPV genotype distribution is showed in Figure 1. All HPVs were episomal, as indicated by RCA, whereas HPV RNA transcripts were undetectable, at least with the sensitivity of the test.

\section{Conclusion}

Data from our study confirms the presence of HPV DNA in skin tags, suggesting the possible role of these viruses in their development. On the other hand, the lack of viral transcripts could indicate a latent infection by HPV.

Furthermore, our data have highlighted the presence of high risk HPVs (types 18 and 16). Given that we examined only 20 patients, we can only hypothesize that skin tags may represent a reservoir of carcinogenic HPVs.

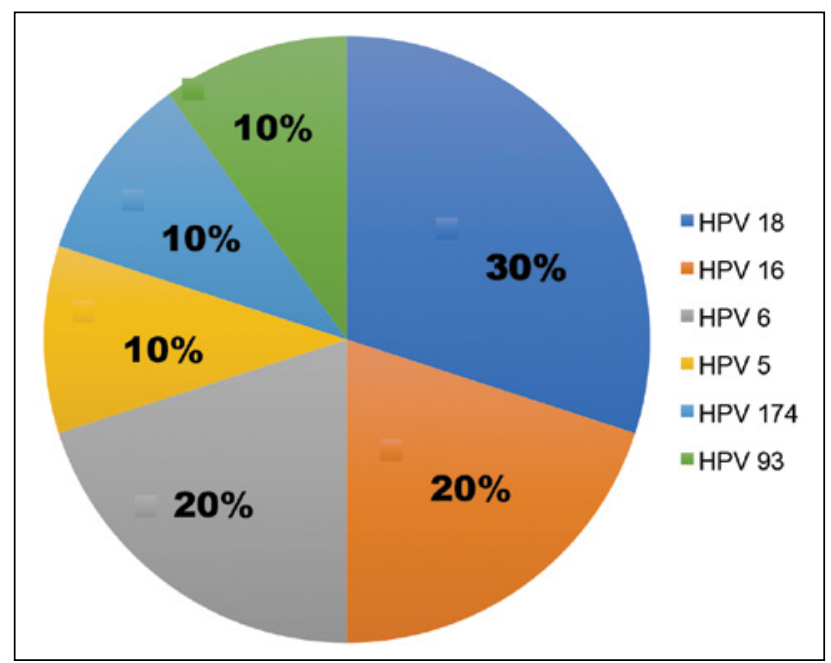

Figure 1. HPV genotypes. Percentages refer to the total number of HPVs plus samples. [Copyright: @2018 Dianzani et al.]

\section{References}

1. Dianzani C, Calvieri S, Pierangeli A, Imperi M, Bucci M, Degener A. M The detection of human papillomavirus DNA in skin tags. Br J Dermatol. 1998;138:(4):649-651.

2. Dianzani C, Paolini F, Conforti C, Riva E, Beninati E, Venuti A. Human papillomavirus expression in immunocompetent patients with actinic keratosis: a case series. J Am Acad Dermatol. 2017;77(4):770-772.

3. Al Shajii A, Al Buainain H. Skin tag in relation with human papilloma virus. The Gulf Journal of Dermatology. 2005;12:31-33. 